\title{
Clinical, Pathological and Imaging findings of Giant Axonal Neuropathy (GAN): report from India with review of literature and differential diagnosis
}

\author{
Pasha SA ${ }^{1}$, Rao DA ${ }^{2}$, Padmaja $A^{3}$, B Anil ${ }^{4}$, A. Mahadevan 5 \\ ${ }^{1}$ Dr. Shaik Afsar Pasha, Department of Neurology, ${ }^{2}$ Dr. D. Ankamma Rao, Department of Radiology, ${ }^{3}$ Dr. A. Padmaja, \\ Department of Radiology, ${ }^{4}$ Dr. B. Anil, Department of Medicine, 1-4 authors are affiliated with NRI Medical College, \\ Chinakakani, Mangalagiri Mandal, Guntur district, Andhrapradesh, India. ${ }^{5}$ Dr. Anitha Mahadevan, Department of \\ Neuropathology, NIMHANS, Bangalore, India. \\ Address for Correspondence: Dr. Shaik Afsar Pasha, Chamber No: 278, Associate Professor of Neurology, NRI Medical \\ College, Chinakakani, Mangalagiri Mandal, Guntur district, Andhra Pradesh, India. E-mail: afsarpasha81@gmail.com
}

\begin{abstract}
Giant axonal neuropathy is a rare autosomal recessive neuro-degenerative disease with simple clinical clues. We describe an 11 year old boy with progressive difficulty in walking with recurrent falls. On examination he had characteristic frizzy curly hair with axonal motor sensory peripheral neuropathy, proximal myopathy, pyramidal and cerebellar signs. Imaging of brain revealed bilateral symmetrical cerebral and cerebellar white matter changes including brainstem and spinal cord. Sural nerve biopsy revealed giant axons of 50-100 microns with tightly packed neurofilaments.
\end{abstract}

Key words: frizzy hair, giant axons, neurodegneration

\section{Introduction}

Giant axonal Neuropathy (GAN) is a rare childhood onset neurodegenerative disorder caused by accumulation of neurofilaments within the swollen axons [1]. Both peripheral and central nervous system are affected [1-3], the commonest clinical manifestations are peripheral neuropathy, cerebellar ataxia, intellectual disability and pyramidal tract

\section{Case Presentation}

11 year old boy, first in birth order, born of consanguineous union, full term, normal delivery, cried immediately after birth with normal birth weight with delay in attainment of motor milestones of development. Parents noted to have progressive difficulty in walking since 3 yrs of age. The time he started walking, he was noted sway to either side requiring support. There was history of difficulty in getting up from squatting requiring support, however no history of Grower`s sign. There was history of slipping of slippers out of the feet while walking with his knowledge, later he could not even grip the slippers. No history of sensory symptoms.

History of Jaundice was present at $3 \mathrm{yr}$ of age which was resolved with treatment. No history of blindness, deafness, seizures. On clinical examination (Fig 1a-1c), had charecteristic facial dysmorphism with high forehead, frizzy curly hair, long philtrum, flat feet with clawing of fingers of the hands. The hair texture was different from that of the parents and the sibling. He had proximo-distal weaknesss of the limbs (distal > proximal) with stance ataxia and gait ataxia requiring support to stand. He had global hyporeflexia in all four limbs with upgoing plantars on both sides. He also had gaze evoked cerebellar nystagmus with normal vision and hearing.

Manuscript received: $11^{\text {th }}$ December 2016

Reviewed: $20^{\text {th }}$ December 2016

Author Corrected: $28^{\text {th }}$ December 2016

Accepted for Publication: $5^{\text {th }}$ January 2017 


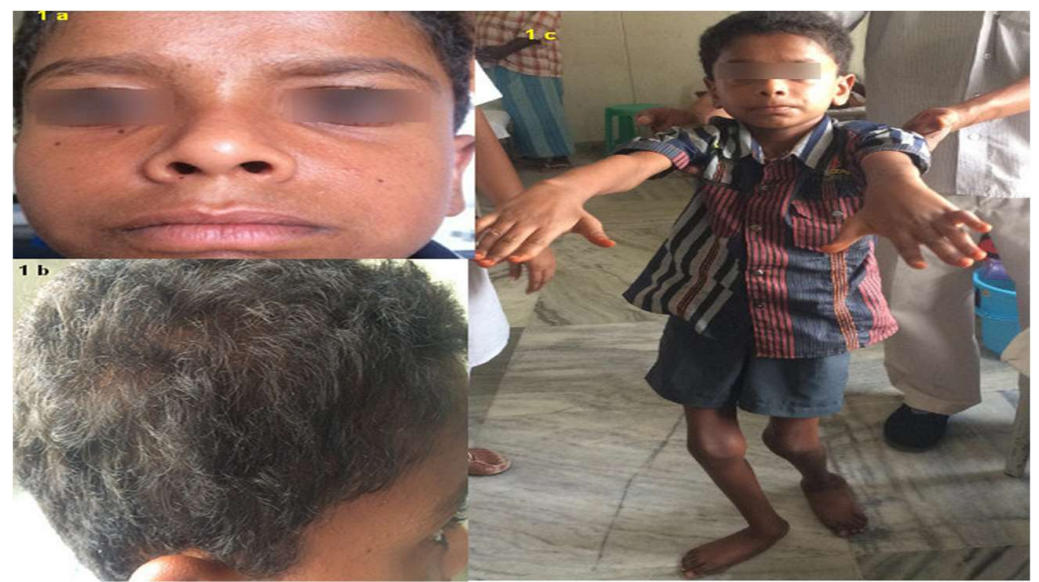

Fig 1a-1b: Clinical photograph of the patient showing high forehead, frizzy and curled hair

Fig 1c- clawing of fingers of left hand with flat feet

Magnetic Resonance Imaging of the Brain and spine (Fig 2a-2d) revealed T1 iso, T2 hyper intensities along the corticospinal tracts from internal capsule, midbrain, pons, medulla and peri-trigonal white matter of Brain and deep white matter of cerebellum including symmetrical dentate nuclear hyperintensity. Spine imaging revealed hyper intensity of cervical spinal cord with atrophy. Electrophysiology of peripheral nervous system revealed severe symmetrical axonal motor more than sensory, lower limb predominant peripheral neuropathy. Visual evoked potentials (VEP) of both eyes revealed normal optic nerve function. EEG showed slowing of background activity however no epileptiform discharges. CSF analysis was within normal limits.

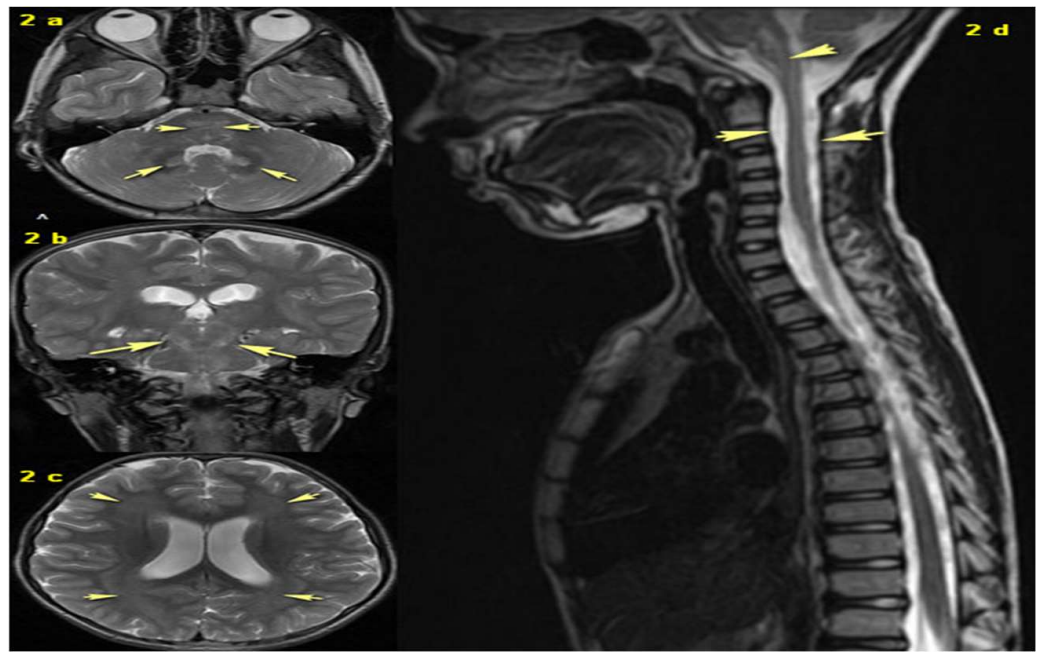

Fig 2a-2d: T2 weighted MRI sequences of brain and spine showing hyperintensities of pons (pontocerebellar fibers), medulla (2a-2d, arrow), symmetrical dentate nuclear hyperintensities of cerebellum (2a axial MRI, arrow), pyramidal tract hyperintensities ( $2 \mathrm{~b}$ coronal MRI, arrow), and periventricular whitematter hyperintensities with sparing of subcortical U fibers, minimal ventriculomegaly (2c axial MRI, arrow) and cervical cord signal changes and atrophy(2d sagittal MRI spine,arrow)

Sural nerve biopsy was done which (Fig 3a-3d) revealed expanded fascicles with several fascicles showing "giant sized distended axons" (ranging from 50-100 micron) that were surrounded by thinned out/absent myelin sheaths. The axonal dilatations were segmental and were filled with phosphorylated neurofilament. Vessels included were normal. Ubiquitin immunostaining highlights the giant axons (Fig 3b). Electron microscopic examination of nerve biopsy tissue (Fig 3d) confirmed the dense accumulation of neurofilaments forming tight fascicles and "Giant axons," the characteristic hallmark of the disease. 


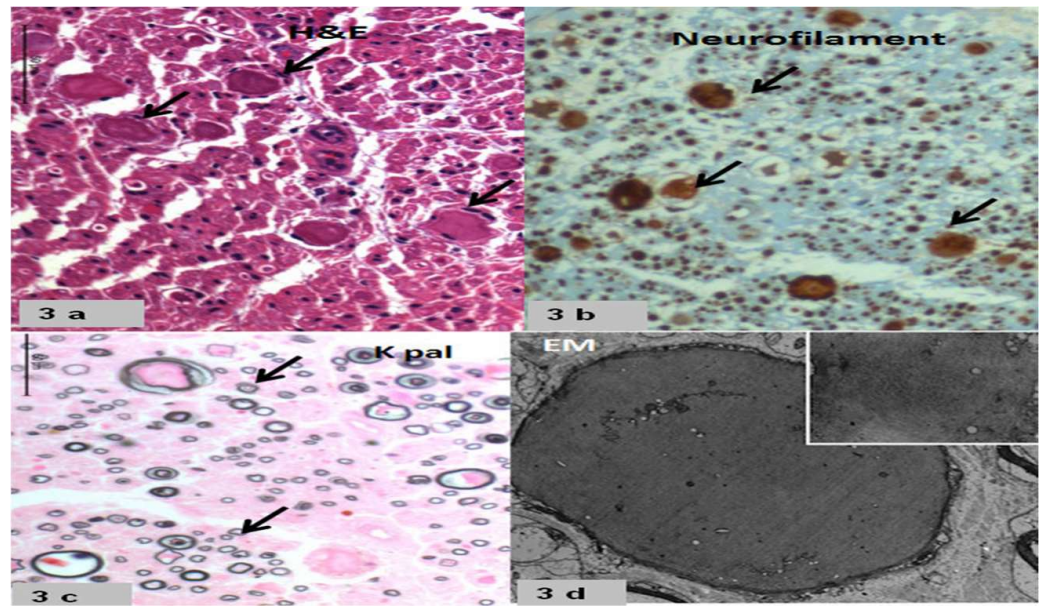

Fig 3a-3d: Sural nerve biopsy shows several distended axons (3a, arrows) that are filled with phosphorylated neurofilament ( $3 b$, arrow) and enclosed by thin attenuated myelin sheaths (3c) (3d) Electron micrograph reveals dense accumulation of neurofilaments forming tight fascicles. Inset shows close up view of neurofilaments. [3a: H\&E stainining, 3b:Neurofilament ubiquitin immunostain (Scale bar=100 microns, 3c: Kulchitsky Pal 9 scale bar=50 microns, 3d:Uranyl acetate-lead citrate x14,000. D, Inset x 36,000]

\section{Discussion}

Our patient was labelled with a diagnosis of 'Giant axonal neuropathy' (GAN) inview of its multiaxial nature of involvement based on classical clinical phenotype, imaging and pathological distinct features. Inheritance pattern of autosomal recessive nature was sought from consanguinous parentage. Clinically he had frizzy curly hair with cerebellar dysfunction at presentation with later progressed to involve peripheral nerves, muscular atrophy, pyramidal system with moderate intellectual disability. Imaging had demonstrated symmetrical whitematter changes of brain (sparing subcortical U fibers), brainstem, cerebellum and cervical spinal cord. Sural nerve biopsy revealed characteristic Focal Giant axons of 50-100 microns. Curly hair is usual however straight hair was associated with milder phenotype.

E Demir et al[4], reported 6 patients of GAN with age at onset of 3.5-4.5 years and all of them had Frizzy hair, peripheral neuropathy, cerebellar signs and Babinski's sign, mental retardation was seen in five, scoliosis and ptosis was observed in four, precocious puberty was seen in two patients. Our patient also had similar findings except ptosis. E Demir et al[4], also described imaging features of brain in 4 patients showing predominant white matter abnormality (anterior to posterior gradient and cerebellar) with cavum septum pellucidum with sparing of basal ganglia and corpus callosum. Our patient had White matter abnormality of cerebrum and cerebellum predominantly in the posterior region with changes of midbrain, pons, medulla and cervical cord. Similar case studies were presented by Vijayakumar et al [5], Kamate et al [6] and Ravishankar et al [7]. As against to published literature of sparing of basal ganglia in GAN, Erol I et al [8] described globus pallidal changes in GAN.

Review of Literature- Giant axonal Neuropathy is a rare autosomal recessive neurodegenerative disease caused by mutations in GAN gene located on chromosome 16q24.1, encoding a protein 'gigaxonin', playing an important role in the regulation of turnover of Intermediate filaments. The first case of GAN was described by Asbury and Berg [1] in 1972, in a 6-year-old girl with kinky hair, progressive clumsiness, muscle weakness and atrophy, areflexia, and sensory loss. The GAN had its onset in childhood around 3 years of age with progressive multi-systemic degenerative disease process involving gastrointestinal, renal, and endocrinal but the major brunt would be on the peripheral nervous system and central nervous system with characteristic facial dysmorphism, skin and hair abnormalities.

Typical presentation would be a child of 3 years of age with facial dysmorphism of high foreheads, pale complexions, and long eyelashes, tightly curled frizzy hair along with progressive sensory motor neuropathy affecting both peripheral and central nervous system manifesting as initial gait disturbance with frequent falls, distal weakness with progressive areflexia, ataxia, dysarthria, dysphagia and wheel chair bound by first decade and death due to respiratory failure by third decade [9]. 
The peripheral neuropathy of GAN is different from certain inherited neuropathies in which there would be a prominent proximal muscle weakness presenting as waddling gait and positive Grower's sign and winging of scapulae and wasting of pectoral muscles. The gastrointestinal manifestations are constipation [10], reflux, regurgitation [11] and lactose intolerance [12]. Endocrinal symptoms are diabetes [13] and precocious puberty [14] and that of renal are renal tubular acidosis [15]. The dermatological symptoms are ichthyosis and keratosis pilaris [15]. Not all patients of GAN do have described curly frizzy hair; the straight hair is correlated with milder neuromuscular phenotype [12].

The diagnostic requisite of GAN is the characteristic clinical phenotype with demonstration of 'Giant Axons' in the peripheral nerve biopsy. However the gold standard diagnostic testing is to detect the mutations in causative gene of GAN [9]. The mutational analysis in our patient could not be done due to logistic reasons. The term 'Giant axonal Neurodegeneration' is more suitable than neuropathy itself because of its multi-axial nature of the disease. Till now there is no effective pharmacological remedy for this disease. Genetic counseling to the parents is of utmost important in the management.

Differential diagnosis and when to consider GAN: The clinical differential diagnosis of GAN is based on its characteristic hair phenotype and axonal pathology. Table 1 illustrates the differentiating features of GAN with similar presenting disease phenotypes [9].

Table-1: Differential diagnosis of Giant Axonal Neuropathy based on clinical, laboratory and imaging findings [9]

\begin{tabular}{|c|c|c|c|c|c|}
\hline $\begin{array}{l}\text { Disease } \\
\text { category }\end{array}$ & Inheritance & Gene & Clinical features & $\begin{array}{c}\text { Giant } \\
\text { Axons in } \\
\text { Peripher } \\
\text { al nerve } \\
\text { biopsy }\end{array}$ & $\begin{array}{l}\text { MRI Brain/Spine } \\
\text { findings }\end{array}$ \\
\hline $\begin{array}{c}\text { Giant } \\
\text { axonal } \\
\text { neuropathy }\end{array}$ & AR & GAN & $\begin{array}{c}\text { Distal and proximal weakness, } \\
\text { ataxia, nystagmus, Kinky frizzy } \\
\text { hair }\end{array}$ & Present & $\begin{array}{c}\text { White matter changes of } \\
\text { brain, brainstem and spinal } \\
\text { cord }\end{array}$ \\
\hline CMT2E & $\mathrm{AD}$ & $\begin{array}{l}\text { Heteroge } \\
\text { nous }\end{array}$ & $\begin{array}{l}\text { Distal weakness and wasting, } \\
\text { loss of sensation. Initial } \\
\text { symptoms include foot drop and } \\
\text { claw toes }\end{array}$ & present & Normal \\
\hline $\begin{array}{c}\text { Infantile } \\
\text { Neuroaxonal } \\
\text { dystrophy }\end{array}$ & $\mathrm{AR}$ & PLA2G6 & $\begin{array}{l}\text { Delay in motor milestones, } \\
\text { muscle weakness and stiffness, } \\
\text { seizure, deafness, blindness }\end{array}$ & $\begin{array}{l}\text { Axonal } \\
\text { spheroid } \\
\text { es }\end{array}$ & $\begin{array}{c}\text { Brain atrophy, white matter } \\
\text { changes, dentate nuclei } \\
\text { hyperintensities, } \\
\text { eye of tiger sign }\end{array}$ \\
\hline $\begin{array}{c}\text { Distal } \\
\text { hereditary } \\
\text { motor } \\
\text { neuropathy }\end{array}$ & $\begin{array}{c}\text { X-linked } \\
\text { recessive: } \\
\text { allelic with } \\
\text { Menkes } \\
\text { disease }\end{array}$ & ATP7A & $\begin{array}{c}\text { General weakness, Patients have } \\
\text { kinky/brittle hair }\end{array}$ & absent & Normal \\
\hline $\begin{array}{l}\text { Fredriechs } \\
\text { ataxia }\end{array}$ & $\mathrm{AR}$ & FXN & $\begin{array}{l}\text { Distal weakness, ataxia, } \\
\text { dysarthria, scoliosis, pescavus, } \\
\text { diabetes, cardiac disease }\end{array}$ & absent & $\begin{array}{l}\text { Normal cerebellum with } \\
\text { spinal cord atrophy }\end{array}$ \\
\hline $\begin{array}{l}\text { Metachrom } \\
\text { atic } \\
\text { leucodystro } \\
\text { phy }\end{array}$ & $\mathrm{AR}$ & ARSA & $\begin{array}{l}\text { Muscle wasting, weakness, } \\
\text { developmental delay, } \\
\text { progressive loss of vision, } \\
\text { Dysphagia, seizures, dementia }\end{array}$ & absent & $\begin{array}{c}\text { Symmetrical confluent } \\
\text { whitematter hyperintensity } \\
\text { in tigroid pattern, sparing } \\
\text { of subcortical U fibers }\end{array}$ \\
\hline $\begin{array}{l}\text { Krabbe`s } \\
\text { disease }\end{array}$ & $\mathrm{AR}$ & GALC & $\begin{array}{l}\text { Muscle weakness and stiffness, } \\
\text { slowing of mental and motor } \\
\text { milestones, seizures }\end{array}$ & Absent & $\begin{array}{c}\text { T2hyperintensities of } \\
\text { bilateral thalami, } \\
\text { periventricular white } \\
\text { matter sparing of } U \text { fibers }\end{array}$ \\
\hline $\begin{array}{c}\text { Spinomusc } \\
\text { ular } \\
\text { atrophy }\end{array}$ & $\overline{\mathrm{AR}}$ & SMN & $\begin{array}{l}\text { Proximal weakness, areflexia, } \\
\text { delayed motor development, } \\
\text { Tongue fasciculations }\end{array}$ & Absent & $\begin{array}{l}\text { Not required, if done } \\
\text { showed T2 hyperintensity } \\
\text { of cervical cord }\end{array}$ \\
\hline
\end{tabular}

CMT2E- Charcot Marie tooth disease type 2E, 


\section{Conclusion}

Even inherited diseases can easily be diagnosed through simple clinical clues if looked carefully. A child presenting with characteristic Tightly curled kinked hair, with progressive sensory motor weakness of limbs, pyramidal, cerebellar signs and mental retardation, think of giant axonal neuropathy.

Funding: Nil, Conflict of interest: None initiated, Perission from IRB: Yes

\section{References}

1. Asbury AK, Gale MK, Cox SC, Baringer JR, Berg BO. Giant axonal neuropathy--a unique case with segmental neurofilamentous masses. Acta Neuropathol. 1972; 20:237-47.

2. Berg BO, Rosenberg SH, Asbury AK. Giant axonal neuropathy. Pediatrics. $1972 ; 49: 894-9$.

3. Carpenter S, Karpati G, Andermann F, Gold R. Giant axonal neuropathy a clinically and morphologically distinct neurological disease. Arch Neurol 1974; 31:3126.

4. Demir E, Bomont P, Erdem S, Cavalier L, Demirci M, Kose G. Giant axonal neuropathy: clinical and genetic study in six cases. J Neurol Neurosurg Psychiatry. 2005;76:825-32.

5. Vijaykumar K, Bindu PS, Taly AB, Mahadevan A, Bharath RD, Gayathri N. Giant axonal neuropathy. J Child Neurol. 2015;30:912-5.

6. Kamate M, Ramakrishna S, Kambali S, Mahadevan A. Giant axonal neuropathy: a rare inherited neuropathy with simple clinical clues. BMJ Case Rep. 2014 Sep $12 ; 2014$.

7. Ravishankar S, Goel G, Rautenstrauss CP, Nalini A. Spectrum of magnetic resonance imaging findings in a family with giant axonal neuropathy confirmed by genetic studies. Neurol India. 2009;57(2):181-4.
8. Erol I, Alehan F, Alkan O, Bruno C. Involvement of the globus pallidus in giant axonal neuropathy. Pediatr Neurol. 2012 Nov;47(5):382-4.

9. Bethany L. Johnson-Kerner, Lisa Roth, J. Palmer Greene, Hynek Wichterle, Douglas M. Sproule. Giant axonal neuropathy: An updated perspective on its pathology and pathogenesis. Muscle and Neve 2014; 50; 467-76.

10. Houlden H, Groves M, Miedzybrodzka Z, Roper H, Willis T, Winer J, Cole G, Reilly MM. New mutations, genotype phenotype studies and manifesting carriers in giant axonal neuropathy. J Neurol Neurosurg Psychiatry. 2007 Nov;78(11):1267-70.

11. Kumar K, Barre P, Nigro M, Jones MZ. Giant axonal neuropathy: clinical, electrophysiologic, and neuropathologic features in two siblings. J Child Neurol 1990; 5:229-34.

12. Roth LA, Johnson-Kerner BL, Marra JD, LaMarca $\mathrm{NH}$, Sproule DM. The absence of curly hair is associated with a milder phenotype in Giant Axonal Neuropathy. Neuromuscul Disord. 2014 Jan; 24(1): 48-55.

13. Hoffman WH, Carroll JE, Perry GY, Hartlage PL, Kaminer SJ, Flowers NC, et al; Giant axonal neuropathy in a child with insulin-dependent diabetes mellitus. J Child Neurol 1995; 10:250-3.

14. Takebe Y, Koide N, Takahashi G. Giant axonal neuropathy: report of two siblings with endocrinological and histological studies. Neuro-pediatrics 1981; 12:392404.

15. Ionasescu V, Searby C, Rubenstein P, Sandra A, Cancilla P, Robillard J. Giant axonal neuropathy: normal protein composition of neurofilaments. J Neurol Neurosurg Psychiatry 1983; 46:551-4.

\section{How to cite this article?}

Pasha SA, Rao DA, Padmaja A, B Anil, A. Mahadevan. Clinical, Pathological and Imaging findings of Giant Axonal Neuropathy (GAN): report from India with review of literature and differential diagnosis. J PediatrRes.2017;4(01): 42-46.doi:10.17511/ijpr.2017.i01.09 